Indexing and Retrieval of Non-Text Information 


\section{Knowledge and Information}

\section{Studies in Information Science}

Editor-in-chief

Wolfgang G. Stock (Düsseldorf, Germany)

Editorial Board

Ronald E. Day (Bloomington, Indiana, U.S.A.)

Sonja Gust von Loh (Düsseldorf, Germany) - Associate Editor

Richard J. Hartley (Manchester, U.K.)

Robert M. Hayes (Los Angeles, California, U.S.A.)

Peter Ingwersen (Copenhagen, Denmark)

Michel J. Menou (Les Rosiers sur Loire, France)

Stefano Mizzaro (Udine, Italy)

Christian Schlögl (Graz, Austria)

Sirje Virkus (Tallinn, Estonia) 


\section{Indexing and \\ Retrieval of Non-Text Information}

Edited by

Diane Rasmussen Neal

DE GRUYTER

SAUR 
ISBN 978-3-11-026057-1

e-ISBN 978-3-11-026058-8

ISSN 1868-842X

Library of Congress Cataloging-in-Publication Data

A CIP catalog record for this book has been applied for at the Library of Congress.

Bibliographic information published by the Deutsche Nationalbibliothek

The Deutsche Nationalbibliothek lists this publication in the Deutsche

Nationalbibliografie; detailed bibliographic data are available in the Internet at http://dnb.dnb.de.

(C)2012 Walter deGruyter GmbH, Berlin/Boston

Printing: Hubert \& Co. GmbH \& Co. KG, Göttingen

$\infty$ Printed on acid-free paper

Printed in Germany

www.degruyter.com 